\title{
HUBUNGAN LAMA MENGIKUTI BABY SPA DENGAN KENAIKAN BERAT BADAN BAYI USIA 0-6 BULAN DI YAYASAN IBU SEJATI MANDIRI KECAMATAN TUNTUNGAN KOMPLEKS MEDAN PERMAI KOTA MEDAN TAHUN 2018
}

\author{
Faradita Wahyuni', Rudi Purwana², Desyi Gusharni Matondang ${ }^{3}$ \\ ${ }^{1}$ Dosen S1 Kebidanan STIKES Senior Medan, Indonesia \\ 2Dosen D3 Keperawatan, Institut Kesehatan Helvetia \\ ${ }^{3}$ Alumni D4 Kebidanan, Institut Kesehatan Helvetia \\ E-mail : dita17f@yahoo.co.id
}

DOI : https://doi.org/10.35451/jkk.v2i2.343

\begin{abstract}
Background; Babies who attend baby spas on a regular basis will produce weight gain of up to $47 \%-80 \%$ for a month, while babies who do not regularly attend baby spas only 2 times a week experience a weight gain of 15-30\%. Objectives;The purpose of this study is to find out the Relationship of the Length in Attending Baby Spa with 0-6 Months Old Baby's Weight Gain at Ibu Sejati Mandiri Foundation Tuntungan Sub District, Komplek Medan Permai Kota in 2018. Method; This type of research is an analytical survey with a cross sectional approach. The population of this study were all infants aged 0-6 months totaling 32. The sample in this study was a 0-6-month-oldin July to September with a total of 32 babies at Ibu Sejati Mandiri Foundation.Results; There is a long relationship following the baby spa with weight gain infants aged 0-6 months with the results of the calculation $p$ value $=0,000<a=0.05$. Conclusion; There is Relationship of the length in attending Baby Spa with Weight gain for 0-6-montholds at Ibu Sejati Mandiri Foundation Medan in 2018. It is suggested for future researchers to be able to make this research as an experience and knowledge, especially about Baby Spa.
\end{abstract}

Keywords: Baby, Baby Growth, Baby's Weight and Baby Spa

\section{PENDAHULUAN}

Bayi merupakan rentang usia 0-12 bulan, dimana pada usia ini bayi mengalami masa kritis. Dikatakan masa kritis dikarenakan bayi mulai beradaptasi terhadap lingkungan sekitarnya, perubahan sirkulasi darah, serta seluruh organ tubuh bayi mulai berfungsi dan adanya perubahan fisik. Bertambahnya jumlah, ukuran berat badan dan tinggi badan bayi yang disebabkan oleh pertumbuhan.

Bayi adalah anak yang berusia 12 bulan. Masa bayi yaitu periode sejak kelahiran sampai usia 11 bulan. Masa bayi ini terbagi menjadi dua bagian, yaitu masa neonatal (sejak kelahiran sampai 28 hari) dan masa sesudah lahir (usia 29 hari sampai dengan 11 bulan).(1) 


\section{Pertumbuhan}

adalah

perubahan yang bersifat kuantitatif, yaitu bertambahnya jumlah, ukuran, dimensi tingkat sel, organ, maupun individu, yang bisa diukur dengan berat (gram, pound, kilogram), ukuran panjang (cm, meter). Menurut Soetijiningsih, 2015, Pertumbuhan fisik yang akan diukur adalah pertambahan berat badan bayi.(2)

Tumbuh Kembang pada anak sudah dimulai sejak berada didalam kandungan ibu sampai dengan usia 18 tahun. Hal ini sesuai dengan pengertian anak, menurut WHO (World Healthy Organization), yaitu sejak terjadinya pembuahan sampai dengan usia 18 tahun.(3)

\section{Data Riskedes}

(2013), pemantauan pertumbuhan bayi yang tidak pernah dilakukan penimbangan berat badan meningkat dari $23,8 \%$ menjadi $34,32 \%$ sehingga dianjurkan melakukan observasi pada anak.(4)

Menurut Kementrian Kesehatan $R I$ sekitar $16 \%$ bayi di Indonesia mengalami terhambatnya pertumbuhan terutamanya berat badan, bahwa bayi yangs sehat dengan bertambah umur maka akan bertambah berat dan tinggi badannya serta bertambah kepandaiannya.(5)

Peningkatan Berat Badan juga merupakan indikator untuk menilai pertumbuhan dan perkembangan bayi. Pertumbuhan bayi pada umumnya dimulai pada 7-10 hari setelah kelahiran.(6)

Saat bayi berusia 4-5 bulan berat badan bayi sudah mencapai dua kali lipat berat badan saat lahir. Pada waktu bayi berumur 1 tahun, berat badan bayi sudah naik menjadi 3 kali lipat berat badan sewaktu bayi dilahirkan.(7)

Faktor pendukung yang sangat menentukan perubahan fisik bagi bayi adalah zat gizi, status kesehatan, ekonomi keluarga dan stimulasi pada bayi. Stimulasi memegang peran penting untuk meningkatkan tumbuh kembang bayi agar dapat berkembang secara maksimal dan dapat mendukung faktor lainnya. (8)

Stimulasi yang diberikan secara rutin dapat merangsang perkembangan sel otak bayi dan memperkuat hubungan jaringan otak yang telah terbentuk. Bentuk rangsangan yang dapat dilakukan kepada bayi adalah Baby Spa (Solus Per Aqua).(9)

Baby Spa berasal dari kata latin yang berarti Baby itu Bayi dan Spa (Solus Per Aqua) Perawatan yang dilakukan dengan Air. Baby Spa dapat diartikan perawatan yang dilakukan untuk bayi dengan media air. Unsur dasar spa salah satunya adalah terapi air (Swim/Berenang), Massage (Pijat) dan Gym (Senam).(10)

Massage adalah terapi pijat tertua dengan memijat yang menggunakan ekstermitas tubuh seperti tangan, jari, siku, kaki atau dapat menggunakan alat bantu lain dengan merangsang jaringan lunak seperti kulit, otot dan syaraf yang memberi efek rangsangan, rileksasi juga melancarkan peredaran darah. Menurut Penelitian yang dilakukan olehProf. T. Field dan Scafidi (1986 dan 1990) menunjukkan bahwa 20 bayi prematur (beratbadan 1280 dan 1176 gram), yang dipijat $3 \times 15$ menit perhari sebanyak $10 x$ dalam waktu lebih kurang 2 minggu, mengalami berat badan meningkat perharinya $20 \%$ sampai $47 \%$ lebih banyak dari yang tidak dipijat. Penelitian pada bayi yang aterm berusia 1-3 bulan, yang dipijat selama 15 menit, seminggu 2 kali selama 6 minggu juga akan mengalami $50 \%$ kenaikan berat badan yang lebih dari kontrol.(11)

Usia 3-6 bulan adalah waktu yang tepat pada bayi untuk melakukan Baby Spa, setelah usia 3 
bulan control pada leher dan tengkuk sudah baik sehingga kepala bayi dapat tegak. Bayi memiliki dua refleks yang dapat membuatnya berenang dengan baik yaitu Reflek Menyelam (Dive Reflek) dan Reflek Berenang (Swim Reflek). Reflek ini akan menyebabkan bayi bisa menahan nafas serta mampu membuka mata mereka ketika berada didalam air. Bayi yang menyelam akan menggerakkan lengan dan kaki dalam gerakan renang, sehingga bayi terlihat seperti perenang alami. Baby Spa bermanfaat memberikan ketenangan, kenyaman, dan kesegaran, sehingga bayi akan relaks dan dapat tidur nyenyak. Dapat diketahui bahwa hormon pertumbuhan $75 \%$ bekerja pada saat bayi tidur. Semakin tinggi jumlah jam tidur bayi pengeluaran hormon pertumbuhan juga meningkat.(12)

Terapi pijat yang dilakukan pada bayi dapat meningkatkan berat badan perhari sampai $20-47 \%$ lebih banyak dari yang tidak melakukan pemijatan jika dilakukan $3 \times 15$ menit selama 10x dalam waktu lebih kurang 2 minggu. Sentuhan pijat bayi akan membuat nafsu makan dan berat badannya meningkat.(13)

Berat badan merupakan hasil peningkatan atau penurunan semua jaringan yang ada pada tubuh, antara lain tulang, otot, lemak, cairan tubuh dan lain-lain. Berat badan digunakan sebagai alat ukur yang terbaik dalam melihat status gizi dan tumbuh kembang bayi. Berat badan bayi menjadi dua kali lipat berat badan lahir pada 6 bulan pertama. Sedangkan pada usia 6-12 bulan berat badan akan meningkat setiap minggunya sekitar 85-400 gram. Akhir tahun pertama Berat anak akan naik 3 kali lipat dari berat badan lahir.(14)
Berdasarkan survei awal yang telah peneliti lakukan di Yayasan Ibu Sejati Mandiri Kota Medan, dari hasil analisis dua bayi berusia 0-6 bulan dengan lama mengikuti Baby Spa dikategorikan dua kelompok.Kelompok pertama tidak rutin mengikuti Baby Spa selama sebulan dan kelompok kedua rutin mengikuti Baby Spa selam sebulan.Ada perbedaan dalam kenaikan berat badan pada kedua kelompok. Bayi pertama usia 0-6 bulan mengikuti Baby Spa selama sebulan tetapi tidak rutin mengalami kenaikan berat badan 15\%- $30 \%$ sekitar 100 gram - 300 gram, bahkan sama sekali tidak mengalami kenaikan berat badan. Bayi kedua usia 0-6 bulan mengikuti Baby Spa secara rutin selama sebulan mengalami progress yang baik dengan berat badan $47 \%-80 \%$ sekitar 500-1000 gram.

Berdasarkan pendahuluan diatas maka peneliti tertarik untuk melakukan penelitian dengan judul "Hubungan Lama Mengikuti Baby Spa dengan Kenaikan Berat Badan Bayi Usia 0-6 Bulan di Yayasan Ibu Sejati Mandiri Kecamatan Tuntungan Kompleks Medan Permai Kota Medan Tahun 2018". Penelitian ini bertujuan Untuk melihat Hubungan Lama Mengikuti Baby Spa Dengan Kenaikan Berat Badan Bayi Usia 0-6 Bulan di Yayasan Ibu Sejati Mandiri Kecamatan Tuntungan Kompleks Medan Permai Kota Medan.

\section{METODE PENELITIAN}

Desain penelitian yang digunakan adalah survey analitik, dimana survey analitik merupakan penelitian yang mencoba menggali bagaimana dan mengapa fenomena itu terjadi.(15) Selanjutnya melakukan analisis dinamika kolerasi antara fenomena, 
baik antara hubungan lama mengikuti baby spa (independen) dan kenaikan berat badan (dependen). Pendekatan yang dilakukan adalah cross sectional, yaitu suatu penelitian dimana cara pengukuran variabel bebas dan variabel terikat dilakukan dalam waktu yang bersamaan.(16)

Penelitian ini akan

dilaksanakan di Yayasan Ibu Sejati Mandiri Kecamatan Tuntungan Kompleks Medan Permai Kota Medan Tahun 2018. Lokasi ini dipilih karena peneliti menemukan adanya Hubungan Lama Mengikuti Baby Spa Dengan Kenaikan Berat Badan Bayi Usia 0-6 Bulan. Waktu yang dilakukan dalam pelaksanaan penelitian ini dilakukan dari bulan Juli sampai bulan September 2018.

Populasi dalam penelitian ini adalah semua bayi usia 0-6 bulan yang berjumlah 32 bayi di Yayasan Ibu Sejati Mandiri Kecamatan Tuntungan Kompleks Medan Permai Kota Medan Tahun 2018. Sampel penelitian ini adalah teknik total sampling yaitu seluruh populasi dijadikan sampel yaitu sebanyak 32 bayi yang berusia 0-6 bulan yang ada di Yayasan Ibu Sejati Mandiri Kecamatan Tuntungan Kompleks Medann Permai Kota Medan.

Pengumpulan data dalam penelitian ini dilaksanakan dengan menggunakan data sekunder diperoleh dari data laporan dokumentasi di Yayasan Ibu Sejati Mandiri bertujuan untk mendukung data yang didapat oleh peneliti. Data tertier adalah data yang diperoleh dari naskah yang sudah dipublikasikan, misalnya WHO, SDKI (Survei Demografi Kesehatan Indonesia), Riskesdas (Riset Kesehatan Dasar).(17)

Analisis data yang digunakan peneliti dalam melakukan penelitian ini yaitu analisis univariat dan analisis bivariat. Analisi univariat adalah analisa data yang menganalisis satu variabel, disebut analisa univariat karena data awal yang diproses dan yang dikumpulkan masih acak dan abstrak, setelah itu baru data diolah agar menjadi informasi yang informative sesuai dengan kenyataan dilapangan. Analisa bivariat yaitu analisa data yang menganalisis dua variabel.(16)

Untuk membuktikan adanya hubungan yang antara signifikan variabel bebas dan variabel terikat digunakan analisis Chi-Square. Uji hipotesis variabel menggunakan nilai signifikansi atau p-value 0,05

\section{HASIL}

Karakteristik pada Sampel menunjukkan bahwa dari 32 responden masing- masing responden yang jenis kelamin bayi laki laki dan jenis kelamin bayi perempuan yang mengikuti Baby Spa yaitu 16 responden (50,0\%). Mayoritas usia bayi pada kategori 4-6 bulan yaitu sebanyak $18(56,3 \%)$ dan Minoritas usia bayi pada kategori 0-3 bulan yaitu sebanyak $14 \quad(43,8 \%)$. Asupan nutrisi bayi mayoritas memberikan ASI yaitu sebanyak 21 $(65,6 \%)$ dan minoritas memberikan ASI + SUFOR yaitu sebanyak 11 (34,4\%) di Yayasan Ibu Sejati Mandiri Kecamatan Tuntungan Kompleks Medan Permai Kota Medan Tahun 2018.

Analisis Univariat pada Tabel 1 menunjukkan bahwa dari 32 responden mayoritas rutin mengikuti Baby Spa yaitu sebanyak 24 responden $(75,0 \%)$, dan minoritas tidak rutin mengikuti Baby Spa yaitu sebanyak 8 responden (25,0\%). Selanjutnya dari 32 responden mayoritas yang mengalami peningkatan berat badan bayi yaitu 24 responden $(75,0 \%)$ yang rutin mengikuti Baby Spa dan yang tidak 
rutin mengikuti Baby Spa tidak mengalami peningkatan berat badan bayi yaitu 8 responden $(25,0 \%)$.

Tabel1: $\quad$ Distribusi Frekuensi Berdasarkan Lama Mengikuti Baby Spa Dengan Kenaikan Berat Badan Bayi, di Yayasan Ibu Sejati Mandiri Kecamatan Tuntungan Kompleks Medan Permai Kota Medan Tahun 2018

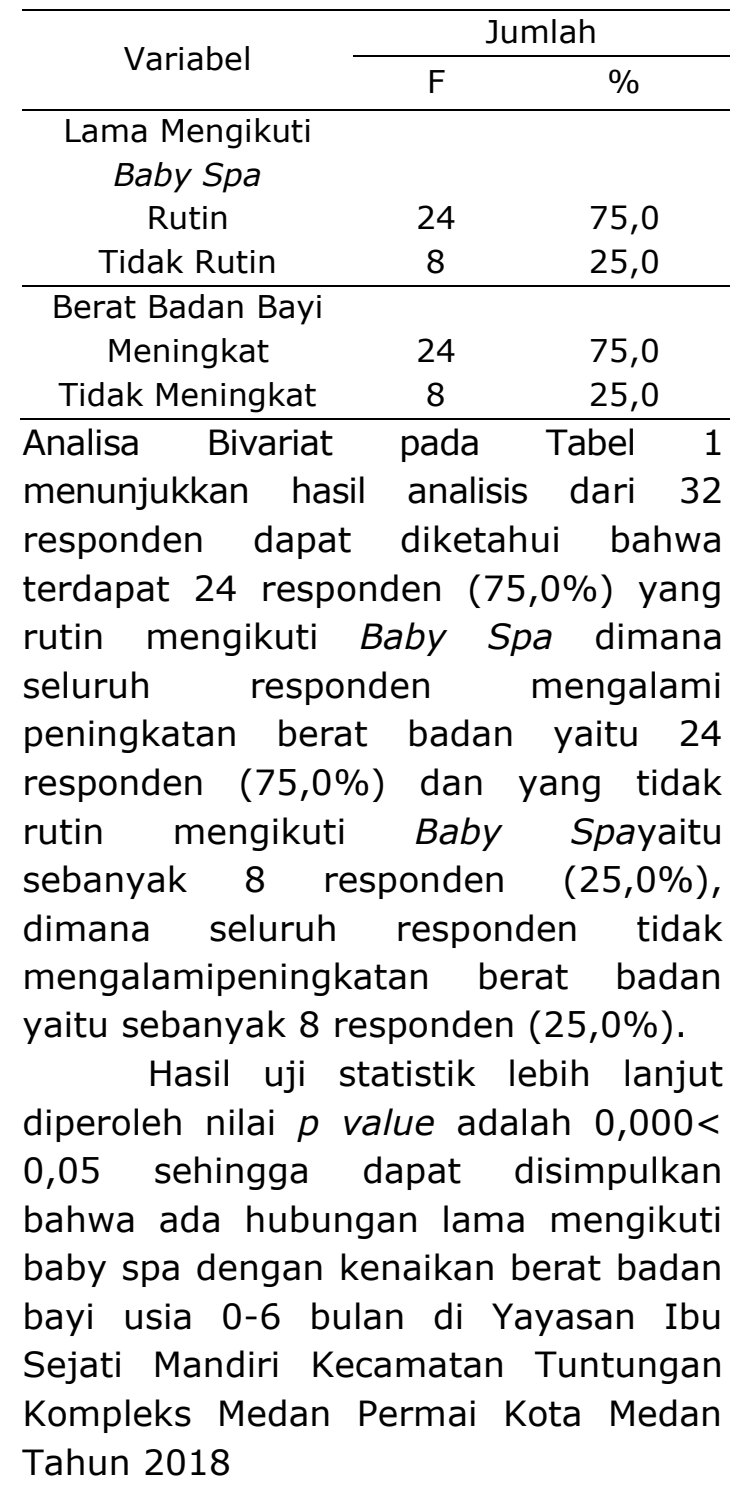

Tabel 2: Hubungan Lama Mengikuti Baby Spa dengan Kenaikan Berat Badan Bayi Usia 0-6 Bulan di Yayasan Ibu Sejati Mandiri Kecamatan Tuntungan Kompleks Medan Permai Kota Medan Tahun 2018.

\begin{tabular}{lll}
\hline Lama & Berat BBL & $p$ \\
\hline
\end{tabular}

\begin{tabular}{|c|c|c|c|c|c|c|c|}
\hline \multirow{2}{*}{$\begin{array}{l}\text { Mengikuti } \\
\text { Baby Spa } \\
\text { Selama } \\
\text { Sebulan }\end{array}$} & \multicolumn{2}{|c|}{ Meningkat } & \multicolumn{2}{|c|}{$\begin{array}{c}\text { Tidak } \\
\text { Meningkat }\end{array}$} & \multicolumn{2}{|l|}{ Total } & value \\
\hline & $f$ & $\%$ & $f$ & $\%$ & $f$ & $\%$ & \multirow{3}{*}{$\begin{array}{c}0,00 \\
0\end{array}$} \\
\hline Rutin & 24 & 75 & 0 & 0 & 24 & 75 & \\
\hline $\begin{array}{l}\text { Tidak } \\
\text { rutin }\end{array}$ & 0 & 0 & 8 & 25 & 8 & 25 & \\
\hline
\end{tabular}

\section{4. pembahasan}

Berdasarkan hasil dilapangan yang dikumpulkan di Yayasan Ibu Sejati Mandiri Kecamatan Tuntungan Kompleks Medan Permai Kota Medan Tahun 2018 dari 32 responden dapat diketahui bahwa terdapat 24 responden $(75,0 \%)$ yang rutin mengikuti Baby Spa dimana seluruh responden mengalami kenaikan berat badan yaitu 24 responden (75,0\%) dan yang tidak rutin mengikuti Baby Spayaitu sebanyak 8 responden $(25,0 \%)$, dimana seluruh responden tidak mengalami kenaikan berat badan yaitu sebanyak 8 responden $(25,0 \%)$.

Hasil uji statistik lebih lanjut diperoleh nilai $p$ value adalah $0,000<$ 0,05 sehingga kesimpulannya adalah ada hubungan lama mengikuti baby spa dengan kenaikan berat badan bayi usia 0-6 bulan di Yayasan Ibu Sejati Mandiri Kecamatan Tuntungan Kompleks Medan Permai Kota Medan Tahun 2018.

Berat badan anak naik pada tahun pertama kehidupan jika mendapatkan gizi yang baik yaitu dar lahir sampai anak usia 6 bulan pertambahan berat badan 140-200 gram setiap minggu. Sentuhan adalah salah satu jenis rangsangan. Hal ini dikemukakan oleh Widyastuti dan Widyani dimana berbagai jenis stimulasi antara lain stimulasi visual, pendengaran, kinetik dan sentuhan. Rangsangan yang selama ini diberikan masyarakat kepada anaknya adalah dengan sentuhan atau pijat.(17) 
Pertumbuhan

dan

Perkembangan anak terjadi mulai dari pertumbuhan dan perkembangan secara fisik, intelektual maupun emosional adalah Pertumbuhan dan Perkembangan Fisik yaitu peristiwa pertumbuhan dan perkembangan secara fisik dapat terjadi dalam suatu perubahan ukuran besar kecilnya fungsi organ mulai dari tingkat sel hingga perubahan organ tubuh, misalnya bertambahnya berat badan atau tinggin badan. Pertumbuhan dan Perkembangan Intelektual yaitu pertumbuhan dan perkembangan intelektual anak dapat dilihat dari kemampuan secara simbolis maupun abstrak seperti berbicara, bermain, membaca, dan lain-lain. Pertumbuhan dan Perkembangan Emosional yaitu perkembangan dan perkembangan emosional dapat diilihat dari perilaku anak ketika berada di lingkungan sosial.(18)

Hasil penelitian ini sejalan dengan penelitian yang dilakukan oleh Dwi Budi Prastiani dan Ikawati Setyaningrum dengan judul "Hubungan Frekuensi Baby Spa dengan Pertumbuhan Bayi usia 3-12 Bulan", dengan dapat disimpulkan sebagai berikut : anak yang melakukan Baby Spa sebagian besar berjenis kelamin laki-laki sebanyak 24 anak dan hanya 14 anak berjenis kelamin perempuan. Frekuensi Baby Spa atau kunjungan pelaksanaan Baby Spa sebagian besar anak melakukan Baby Spa secara rutin sebanyak 29 anak dan hanya 9 anak yang melakukan Baby Spa secara tidak rutin. Pertumbuhan fisik pada anak yang melakukan Baby Spa sebagian besar mengalami pertumbuhan fisik yang normal sebanyak 27 anak dan hanya 11 anak yang mengalami pertumbuhan fisik yang tidak normal.
Penelitian yang telah dilaksanakan oleh Dwi Tariva dan Siti Khotimah di Fatih Baby Spa dan Fisioterapi Tumbuh Kembang Anak dan Desa Pundung Kecamatan Gamping Yogyakarta selama empat minggu dengan menggunakan Eksperimental dan dengan racangan penelitian pre dan post two group design pada tanggal 30 Mei 2016. Dari 24 sampel dibagi menjadi 2 kelompok masing-masing kelompok berjumlah 12 sampel. Kelompok 1 diberikan perlakuan massage baby dan kelompok 2 diberikan perlakuan Baby Spa. Pada kelompok 1 diberikan perlakuan massage baby. Pada bayi usia 0-6 minggu diberi gerakan usapan halus dan sebelum tali pusat lepas tidak dipijat di daerah perut, bayi dengan usia 1-3 bulan diberikan pijatan halus dengan tekanan ringan. Setelah bayi berusia 3 bulan keatas bayi diberikan pijat dengan tekanan yang lebih. Pada kelompok 2 diberikan perlakuan Baby Spa yang terdiri dari Baby Swim dan pijat bayi. Pijat bayi dilakukan 30 menit, setelah itu dilanjutkan dengan baby swim selama 15 menit dengan air hangat. Peningkatan berat badan bayi mencapai $\geq 50-89 \%$.

Hasil penelitian Wulan Marigiana menujukan bahwa Baby Spa berpengaruh terhadap kenaikan berat badan bayi di Rumah Sehat Kita Purwokerto $(p=0,001)$. Temuan penelitian menunjukkan hasil yang relevan dengan penelitian Sumini at all, yang berjudul pengaruh pijat bayiterhadap pertambahan berat badan bayi di Desa Karang Wasen Kecamatan Jiwan Kabupaten Madiun dengan hasil adapengaruh pijat bayi terhadap pertambahan berat badan bayi usia 1-6 bulan di Desa Karang Wasen Kecamatan Jiwen Kabupaten Madiun. Dari hasil uji t tersebut terlihat bahwa nilai signifikan sebesar 0,00 Keputusan 
uji statistic Haditerima bila $\mathrm{p}<0,05$ Maka dapat disimpulkan $0,00<0,05$, artinya ada pengaruh pijat bayi terhadap pertumbuhan berat badan bayi usia1-6 bulan di Desa Karang Wasen Kecamatan Jiwan Kabupaten Madiun. Hal ini sesuai dengan penelitian yang dilakukan oleh Tri dkk, yang menunjukan bahwa uji mann whitney didapatkan $p$ valuesebesar $0,01 \quad(p<0,05)$ sehingga pemberian terapi pijat berpengaruh terhadap peningkatan berat badan sesuai dengan hasil penelitian Sumini at all dan Tri Sasmi Irva at all bahwa Baby Spa berpengaruh terhadap peningkatan berat badan bayi.

Spa adalah singkatan dari sehat pakai air. Spa adalah suatu sistem pengobatan atau perawatan dengan media air atau istilahnya hidrotherapi. Spa Baby (Baby Spa) adalah perawatan tubuh bayi yang dilakukan secara menyeluruh mulai dari pemanasan (Baby Gym), bayi renang (Baby Swim) dan pijatan (Baby Massage). Berat badan lahir adalah berat badan bayi yang di timbang 24 jam pertama kelahiran.(19)

Senam Bayi (Baby Gym) adalah latihan untuk membantu stimulasi pertumbuhan dan perkembang sistem saraf dan motorik bayi. Waktu yang tepat melakukan Baby Gympada pagi hari dan malam hari menjelang tidur, dilakukan dua kali sehari selama 5-10 menit. Manfaat Baby Gym adalah menguatkan otot-otot dan persendian, meningkatkan perkembangan motorik, meningkatkan fleksibilitas atau daya kelenturan tubuh, dan menguatkan jantung, serta meningkatkan pasokan oksigen ke dalam otot menjadi lebih banyak.

$$
\text { Berenang (Baby Swim), }
$$

Penelitian di Melbourne, Australia, menunjukkan bahwa iq anak-anak yang diajarkan berenang sejak bayi terlihat lebih tinggi ketimbang anakanak yang tak diajarkan berenang. Manfaat Baby Swim adalah untuk merangsang gerakan motorik bayikeseimbangan tubuh lebih baik, bayi tidak takut terhadap air, mengasuh kemandirian, keberanian dan kepercayaan diri, meningkatkan iq (kecerdasan berpikir dan konsentrasi), sarana bermain yang menyenangkan bagi bayi, meningkatkan kualitas tidur siang dan malam hari, nafsu makan meningkat, dan berbicara lebih cepat

Pijat bayi (Massage Baby) adalah mengurut bagian tubuh untuk melemaskan otot sehinggan peredaran darah lancar. Pijat bayi dapat dilakukan setiap hari yaitu pada pagi hari dan malam hari sebelum tidur. Waktu pemijatannya 10-15 menit dilakukan 2 kali sehari, dengan kondisi bayi tenang dan santai.(10) Manfaat Pijat bayi adalah meningkatkan daya tahan tubuhmeningkatkan berat badan, membuat bayi semakin tenang, membuat bayi tidur lelap, menigkatkan pertumbuhan dan perkembang motorik, mningkatkan konsntrasi bayi, memacu perkembangan otak dan sistem saraf, merangsang fungsi pencernaan serta pembuangan, memperkuat ikatan bonding bayi dengan ibu / orang tuanya, meningkatkan aliran oksigen dan nutrisi menuju sel, bayi merasa aman, mengurangi hormon stress, kulit bayi lebih halus, dan mengajari bayi sejak dini tentang bagian tubuh

Usia 3-6 bulan adalah saat tepat bagi bayi untuk mulai melakukan baby spa. Setelah usia 3 bulan neck control sudah baik sehingga kepala bayi dapat tegak. Bayi juga memiliki sepasang refleks yang dapat membuat mereka berenang dengan baik yaitu refleks menyelam (dive refleks), dan reflek berenang (swim refleks). 
Bayi yang mengikuti Baby Spa secara rutin akan menghasilkan kenaikan berat badan hingga 47\%$80 \%$ selama sebulan, sedangkan bayi yang tidak rutin mengikuti baby spa selama sebulan mengalami kenaikan berat badan $15 \%-30 \%$ dan bahkan tidak ada peningkatan. Dengan rutin melakukan Baby Spa akan meningkatkan menstimulasi enzimenzim yang ada di perut sehingga penyerapan nutrisi dalam tubuhnya lebih optimal.

Kenaikan berat badan anak pada 1 tahun pertama kehidupan jika anak diberikan gizi dengan baik yaitu dari bayi 0 sampai 6 bulan pertama pertambahan berat badan setiap minggunya 140-200 gram. Sentuhan merupakan salah satu jenis stimulasi. Hal ini dikemukakan oleh Widyastuti dan Widyani dimana jenis-jenis stimulasi dapat berupa stimulasi visual, pendengaran, kinetik dan sentuhan. Stimulasi sentuhan yang selama ini diberikan masyarakat kepada anaknya adalah dengan sentuhan atau pijat.

Menurut Guyton (dalam Ganong, 1999) bahwa pemijatan yang dilakukan pada bayi akan membantu perkembangan nervus vagus, dimana saraf ini akan meningkatkan peristaltik usus untuk mengosongkan lambung, dengan begitu bayi cepat lapar, sehingga masukan makanan akan meningkat. Syaraf ini juga membantu peningkatan produksi enzim pencernaan dengan baik, sehingga penyerapan nutrisi meningkat.

\section{KESIMPULAN}

Hasil penelitian dapat disimpulkan bahwa Ada hubungan antara Lama Mengikuti Baby Spa dengan Kenaikan Berat Badan Bayi Usia 0-6 Bulan di Yayasan Ibu Sejati Mandiri Kecamatan Tuntungan Kompleks Medan Permai Kota Medan Tahun 2018.

\section{DAFTAR PUSTAKA}

Soetjiningsih. Tumbuh Kembang Anak. I. Yogyakarta: Nuha Medika; 2014. 1-249 p.

Prastiani DB, Setyaningrum I. Hubungan Frekuensi Baby Spa Dengan Pertumbuhan Fisik Bayi Usia 6-12 Bulan. 2017;4(November 2016):80-4.

Rahayu S, Suherni T, Runjati. Pengaruh Baby Spa Terhadap Kenaikan

Berat Badan dan Perkambangan Bayi Umur 3-6 Bulan. J Kebidanan. 2015;11:6.

Kalsum U. Peningkatan Berat Badan Bayi Melalui Pemijatan. 2014;17(1):25-9.

Margiana W, Muflihah IS. Pengaruh Baby Spa Terhadap Kenaikan Berat Badan Bayi. 2018;10:2931.

Oktiawati A, Julianti E. Pengaruh Baby Spa Terhadap Perkembangan Kemampuan Motorik Kasar Bayi Di My Baby Spa Surabaya Esti Rachmawati Wahyuningtyas Universitas Negeri Surabaya, Titi_ian@ymail.com Abstrak. Pengaruh Baby Spa Terhadap Perkemb Kemamp Mot Kasar Bayi Di My Baby Spa Surabaya. 2017;06:241-5.

Muslihatun WN, Santi MY. Hubungan Frekuensi Baby Spa Dengan Perkembangan Bayi Usia 4- 6 Bulan. Kebidanan dan Keperawatan [Internet]. 2015;11(1):41-50. Available from:

http://digilib.unisayogya.ac.id/23 48/1/5jurnal JKK -juni15 OK.pdf $\#$ page $=43$

Rohmah S, Astuti I, Rosyeni Y. Efektivitas Baby Spa Terhadap Lama Tidur Bayi Usia 3-4 Bulan Di BPM Bidan Siti Fatimah Kota Cimahi Tahun 2016 Effectiveness Of Baby Spa To Long Sleep Baby 
In 3-4 Months At Siti Fatimah Midwife Practice Cimahi City Year 2016 Pendahuluan pertumbuhan Dan Per. 2016;2(02):74-80.

Rahayu UB. Pengaruh Baby Solus Per Aqua Terhadap Peingkatan Berat Badan Pada Bayi Dengan Berat Badan Rendah Usia 4-6 Bulan. 2015;

Julianti. Rahasia Baby SPA. I. Jakarta: Writerpreuneur Club; 2017. 14, 26, 37, 48 p.

Martha, G.A.Winingsih, SST, MM MK. Hubungan Pengetahuan Dengan Sikap Ibu Balita Pijat Bayi di BPM WAHIDAH, SST. Vol. 6. Jakarta; 2016.

Wahyuningsih SE, Setiyowati W, Akademi D, Abdi K, Semarang $H$, Akademi $D$, et al. Hubungan Tingkat Pengetahuan Dengan Perkembangan Bayi Usia 6-12 Bulan Di Klinik Little Angel Mapagan Ungaran Kabupaten Semarang. 2018;II(3):2-6.

Minarti NMA, Utami KC. Pengaruh Pijat Bayi Terhadap Kualitas Tidur Bayi Usia 3-6 Bulan di Wilayah Kerja Puskesmas II Denpasar Timur. Fak Kedokt Univ Udayana. 2012;1(1).

Suryani E dan BA. Asuhan Keperawatan Anak Sehat dan Berkebutuhan Khusus. I. Yogyakarta: PUSTAKA
BARU PRESS; 2017. 57 p.

Muhammad I. Panduan Penyusunan Karya Tulis Ilmiah Bidang Kesehatan Menggunakan Metode Penelitian Ilmiah. V. Suroyo BR, editor. Medan: Cita Pustaka Media Perintis; 2016.

Sugiyono. Metode Penelitian Kuantitatif, Kualitatif Dan R\&D. 20th ed. Vol. 32, Fenxi Huaxue. Bandung: Alfabeta; 2004. 1365$1367 \mathrm{p}$.

Suprapto H. Metodologi Penelitian untuk Karya Ilmiah. I. Yogyakarta: Gosyen Publishing; 2017. 73 p.

Taradiva D, Khotimah S. Perbedaan Pengaruh Pemberian Massage Baby Dan Spa Baby Terhadap Peningkatan Gross Motor Pada Bayi Di Bawah Usia 6 Bulan. 2016;72(10):1-13.

Menkes RI. Peraturan Mentri Kesehatan Republik Indonesia Nomor 8 Tahun 2014 [Internet]. 2014. Available from: http://www.hukor.depkes.go.id/ uploads/produk_hukum/PMK No. 8 ttg Pelayanan Kesehatan SPA.pdf 